\title{
Effect of pre- and post-weaning dietary supplementation with arginine and glutamine on rabbit performance and intestinal health
}

Rebeca Delgado', Rodrigo Abad-Guamán', Nuria Nicodemus', Araceli Diaz-Perales², Javier García', Rosa Carabaño ${ }^{1}$ and David Menoyo ${ }^{1 *}$ (D)

\begin{abstract}
Background: The purpose of the present study was to assess if the exposure to glutamine (GIn), arginine (Arg) or their combination from pregnancy, through the maternal diet, to a post weaning supplemented diet, can stimulate litter performance, gut development and immune function. To this end does and their litters were fed the same basal diet no supplemented (control C), or supplemented with $0.4 \% \mathrm{Gln}, 0.4 \% \mathrm{Arg}$, or $0.4 \mathrm{Gln}+0.4 \mathrm{Arg}$. Rabbits were weaned at $25 \mathrm{~d}$ of age and fed the same experimental diet as their mothers for 10 additional days (35 d of age). Bacterial translocation to mesenteric lymph nodes (MLN) at $6 \mathrm{~d}$ of age and intestinal histology, enzymatic activity, phenotypical and functional analysis of intraepithelial lymphocytes (IEL) from the appendix were determined at 6,25 and $35 \mathrm{~d}$ of age.
\end{abstract}

Results: No significant differences on animal performance or mortality rates were observed among dietary treatments. However, kits from rabbit does supplemented with Gln tended $(P \leq 0.10)$ to reduce the translocation of total number of both aerobic and facultative anaerobic bacteria to the MLN. Also, rabbits fed the Gln supplemented diets maintained intestinal villous height at weaning compared to the non-supplemented diets $(P<0.05)$. The proportions of $C D 45^{+} C D 4^{+}$ and $\mathrm{CD}_{4} 5^{+} \mathrm{CD} 8^{+}$IEL in the appendix were not affected by dietary means. However, in rabbits IEL at weaning dietary GIn significantly upregulated IL-2 and downregulated IL-6 expression.

Conclusions: Despite a lack of effect on performance and mortality the inclusion of $0.4 \%$ Gln has a positive effect by maintaining intestinal villous height and modulating the cytokine profile at weaning. The supplementation with Arg or $\mathrm{Arg}+\mathrm{Gln}$ at the selected doses in this study did not exert positive effects on rabbit intestinal health.

Keywords: Arginine, Glutamine, Rabbit, Gut health

\section{Background}

The use of feed additives is becoming a common practice to prevent diseases in young productive animals [1]. Amino acids with functional properties such as arginine (Arg) and glutamine (Gln) have been proven to be nutritionally essentials for neonates and under stressful conditions such as weaning [2-5].

\footnotetext{
* Correspondence: david.menoyo@upm.es

'Departamento de Producción Agraria, ETSI Agronómica, Alimentaria y de Biosistemas, Universidad Politécnica de Madrid, Ciudad Universitaria, Madrid, Spain

Full list of author information is available at the end of the article
}

Despite Arg can be synthetized from other amino acids (Gln, glutamate and proline) it is considered an essential amino acid in young animals as their needs exceeds endogenous synthesis $[3,6]$. Arginine is an important $\mathrm{N}$ carrier and precursor for amino acids, proteins and polyamines needed for immune cell proliferation [2]. Also, it is a substrate for the synthesis of nitrogen oxide $(\mathrm{NO})$ a powerful mediator in both innate and adaptive immunity [6]. Arginine supplementation $(0,5-1 \% \mathrm{w} / \mathrm{w})$ to young pigs supports intestinal epithelial growth and maintains gut barrier integrity and function against bacterial toxins [6].

(c) The Author(s). 2019 Open Access This article is distributed under the terms of the Creative Commons Attribution 4.0 International License (http://creativecommons.org/licenses/by/4.0/), which permits unrestricted use, distribution, and reproduction in any medium, provided you give appropriate credit to the original author(s) and the source, provide a link to the Creative Commons license, and indicate if changes were made. The Creative Commons Public Domain Dedication waiver (http://creativecommons.org/publicdomain/zero/1.0/) applies to the data made available in this article, unless otherwise stated. 
Glutamine is also considered an indispensable amino acid for intestinal development and function [2, 6, 7]. It provides energy and it is the precursor for other amino acids (including citrulline, Arg and glutamate) and derivatives needed for enterocyte and immune cells function and proliferation $[2,6]$. Moreover, it has been proven to play important roles under disease and stress situations by maintaining epithelial integrity and gut associated lymphoid tissue (GALT) function [3, 6, 7]. Recently, beneficial effects of Gln on gut health have also been associated to a direct use of this amino acid by commensal bacteria [8].

Several authors observed that the combination of Arg and Gln have beneficial additive effects [9-11]. Our previous research with growing rabbits showed that diets supplemented with $1 \%$ of Gln and $0.5 \%$ of Arg tend to improve productive performances reducing the presence of Clostridium spp. and Helicobacter ssp. in the caecum and in the ileum [12]. Moreover, ex vivo experiments suggest that the combination of Arg and Gln decrease the production of pro-inflammatory cytokines [13].

The aim of this study was to determine if the rabbit gastrointestinal tract development and function is positively affected by feeding pre-weaning (pregnancy period) and post-weaning diets supplemented with Arg, Gln and their interaction.

\section{Methods}

\section{Animals and housing}

Rabbits were handled following the principles and guidelines of care of animals in experimentation (Spanish Royal Decree, 53/2013, BOE, 2013) which meets the European Union Directive 2010/63/EU about the protection of animals used in experimentation. Rabbits (New Zealand White $\times$ Californian, $\mathrm{V} \times \mathrm{R}$ genetic hybrids from Universidad Politécnica de Valencia, Valencia, Spain) were offspring of primiparous does breed at our facilities. They were nursed by their mothers until 25 days of age. Rabbit does were housed individually and kept under controlled environmental conditions with $18-23^{\circ} \mathrm{C}$ and $16 \mathrm{~h}$ daily lighting. An external nestbox with wood shavings was provided three days before parturition. Nulliparous rabbit does were assigned randomly to the four treatments (20 per diet) at $123 \mathrm{~d}$ of age, 6 days before the first artificial insemination (AI), with a body weight (BW) of $3.6 \pm 0.1 \mathrm{~kg}$. Forty eight $\mathrm{h}$ before insemination, the does were injected $25 \mathrm{IU}$ of equine chorionic gonadotropin (Segiran, Lab. Ovejero, León) to synchronize oestrus. The day of insemination, does received an intramuscular injection of $1 \mu \mathrm{g}$ of buserelin Suprefact ${ }^{\oplus}$ (Hoechst Marison Roussel, S.A., Madrid), a Gonadotropin-releasing hormone agonist (GnRH agonist), to induce ovulation in rabbit does [14]. At the time of weaning ( 25 days of age) rabbits were housed collectively in groups of 2 or 3 animals per cage
$(650 \mathrm{~mm} \times 250 \mathrm{~mm} \times 330 \mathrm{~mm})$. Four hundred and seventy one rabbits weighting $390 \pm 82 \mathrm{~g}$ were allocated into 190 cages and assigned the same dietary treatment as during the lactating (pre-weaning) period. Housing conditions were controlled during the whole experimental period. The farm temperature was maintained between 18 and $24{ }^{\circ} \mathrm{C}$ with $12 \mathrm{~h}$ of light and $12 \mathrm{~h}$ of darkness.

Therefore, in total 559 rabbits were used in this study, of them 88 were slaughtered at 6 and 25 days of age to collect samples. The remaining 471 were used to analyze growth performance (from 25 to 35 days of age). A final sampling of 40 rabbits with 35 days of age was done to complete the 6, 25 and 35 days of age sample set to analyze dietary effects on selected intestinal health variables. The maximum number of replicates was fixed for weight gain assuming changes in means expected between groups of $3.5 \mathrm{~g}$ per day and a standard deviation of 6 using a power of test of $80 \%$ (1-beta) and a significant level of 0.05 (alpha).

\section{Experimental diets and growth performance}

Four diets were used following a $2 \times 2$ factorial arrangement (two levels of Arg combined with two levels of Gln). A control diet (C) was formulated to contain 19.1\% protein and 35.3\% NDF (on DM basis) and meeting the minimal nutrient requirements [15]. Three other diets were obtained by adding on top to the control diet $0.4 \%$ Arg (Arg diet), 0.4\% Gln (Gln diet) or 0.4 Gln + 0.4 Arg (Gln + Arg diet). L-Glutamine and Arg were provided by Indukern S.A. (Barcelona, Spain). Arginine and Gln doses were fixed according to the positive effects on rabbit health observed in previous studies [14]. The ingredient and chemical composition of experimental diets are shown in Tables 1 and 2. Rabbits had ad libitum access to feed and water, and each litter received the same diet as its mother. Therefore, rabbits were exposed to Arg and Gln or their combination during lactation through the maternal diet and after weaning. Feed intake, body weight gain and feed efficiency were estimated $10 \mathrm{~d}$ after weaning (day 35), whereas mortality was recorded daily.

\section{Chemical analysis}

Procedures of the AOAC [16] were used to determine the dietary concentrations of DM (934.01), ash (942.05) and CP (954.01). Dietary NDF, ADF and ADL were determined sequentially using the filter bag system (Ankom Technology, New York, NY) [17]. Gross energy was measured by adiabatic bomb calorimeter (model 356, Parr Instrument Company, Moline, IL). Amino acids were determined after acid hydrolysis using a Beckman System 6300HPA AA analyzer (Fullerton, CA). Samples were hydrolyzed by reflux in $25 \mathrm{~mL}$ of $6 \mathrm{M} \mathrm{HCl}$ with $10 \mathrm{~g} / \mathrm{L}$ of added phenol for $24 \mathrm{~h}$ at $120^{\circ} \mathrm{C}$. For the determination of sulfur AA (Met and Cys), samples were 
Table 1 Ingredient composition of the control diet ( $/ \mathrm{kg} \mathrm{DM}$ )

\begin{tabular}{lc}
\hline Ingredients & $C$ \\
\hline Alfalfa hay & 290 \\
Wheat & 220 \\
Wheat straw & 220 \\
Sunflower meal 28-30 & 130 \\
Soybean meal 44 & 65.0 \\
Soy protein concentrate 61 & 15.0 \\
Defatted grape seed meal & 20.0 \\
Lard & 20.0 \\
L-Lysine HCl & 2.00 \\
DL-Methionine & 0.50 \\
L-Threonine & 0.50 \\
Calcium carbonate & 6.80 \\
Sodium chloride & 5.00 \\
Vitamin/mineral premix ${ }^{a}$ & 5.00 \\
Coccidiostat ${ }^{b}$ & 0.20 \\
\hline aProvided by Trouw Nutrition-Tecna (Madrid, Spain). Mineral and vitamin \\
composition (mg/kg): Mn: 4000; Zn: 11840; Cu: 2000; I: 250; Co: $99 ;$ Fe: $15200 ;$ \\
Niacin: 4000; Betaine: 10830; Choline: 27500; Vitamin K: 200; Vitamin B1: 200; \\
Vitamin B2: 400; Vitamin B6: 200; Vitamin A: 1675000Ul/kg; Vitamin D3: 150000 \\
Ul/kg; Vitamin E (a-tocopherol acetate): 4000Ul/kg. ${ }^{\text {1 } 1 ~ p p m ~ d i c l a z u r i l ~ p r o v i d e d ~}$ \\
Esteve (Barcelona, Spain) &
\end{tabular}

oxidized with per-formic acid at $0{ }^{\circ} \mathrm{C}$ for $16 \mathrm{~h}$ and then neutralized with $0.5 \mathrm{~g}$ of sodium meta-bisulphite before analysis. During acid hydrolysis, tryptophan was destroyed and was not determined.

\section{Bacterial translocation to mesenteric lymph nodes}

Six days after parturition 24 kits, one per litter (24 litters; 6 litters/diet), were randomly selected from out of the 14 litters per treatment included in the study (see [14] for details) and slaughtered by cervical dislocation at 12:00 h a.m. The mesenteric lymph nodes (MLN) located at the base of the small-bowel mesentery was excised completely under sterile conditions for bacterial analysis. The nodes, weighing on average $19 \pm 9 \mathrm{mg}$, were dissected free from fat and placed in a sterile eppendorf containing $1 \mathrm{ml}$ of sterile peptone water. Later, they were homogenized using a mixer mill (Reisch MM 400) by applying a frequency of $22 \mathrm{~Hz}$ during $2 \mathrm{~min}$. Each $\mathrm{ml}$ of MLN homogenized was blended with $9 \mathrm{ml}$ of peptone water and diluted (3 dilutions per sample). Dilutions were plated onto blood agar (columbia agar + sheep blood, Oxoid S.A.). For aerobes analysis plates were incubated at $37^{\circ} \mathrm{C}$ for $48 \mathrm{~h}$ in aerobic conditions. For anaerobes analysis plates were incubated in jars of 61 with anaerobic atmosphere (two AeroGen 3.51 per jar; Oxoid S.A.). Facultative anaerobes microorganisms were incubated in jars of 61 with one carbon dioxide generating envelopes (AeroGen 3.5 l; Oxoid S.A.). For each analysis, a blank with sterile
Table 2 Chemical composition of experimental diets ( $\mathrm{g} / \mathrm{kg} \mathrm{DM}$ )

\begin{tabular}{|c|c|c|c|c|}
\hline Diets & C & Arg & Gln & $\operatorname{Arg}+\mathrm{Gln}$ \\
\hline Arginine & 0 & 0.4 & 0 & 0.4 \\
\hline Glutamine & 0 & 0 & 0.4 & 0.4 \\
\hline \multicolumn{5}{|c|}{ Analyzed composition, g/kg DM } \\
\hline Dry matter & 899 & 893 & 897 & 901 \\
\hline Ash & 67.5 & 71.2 & 68.9 & 71.0 \\
\hline Nitrogen & 29.8 & 30.6 & 30.1 & 30.4 \\
\hline Ether extract & 50.0 & 50.0 & 47.0 & 45.0 \\
\hline Total dietary fibre & 418 & 423 & 426 & 425 \\
\hline Neutral detergent fibre & 313 & 322 & 319 & 321 \\
\hline Acid detergent fibre & 179 & 174 & 176 & 179 \\
\hline Acid detergent lignin & 48.1 & 44.6 & 45.6 & 44.1 \\
\hline Soluble fibre & 105 & 101 & 107 & 105 \\
\hline Gross energy (MJ/kg DM) & 18.0 & 18.5 & 18.4 & 18.4 \\
\hline \multicolumn{5}{|l|}{ Amino acids, g/kg DM } \\
\hline Alanine & 8.00 & 7.90 & 8.00 & 8.00 \\
\hline Arginine & 11.3 & 15.3 & 11.6 & 15.3 \\
\hline Aspartic acid & 16.1 & 16.0 & 15.9 & 16.1 \\
\hline Cystine & 2.90 & 2.90 & 2.90 & 2.90 \\
\hline Glutamic acid & 30.8 & 30.3 & 34.5 & 35.3 \\
\hline Glycine & 8.70 & 8.60 & 8.70 & 8.70 \\
\hline Histidine & 4.00 & 3.90 & 4.00 & 3.90 \\
\hline Isoleucine & 6.90 & 6.70 & 6.80 & 6.60 \\
\hline Leucine & 11.9 & 11.8 & 11.8 & 11.9 \\
\hline Lysine & 9.30 & 9.20 & 9.20 & 9.20 \\
\hline Methionine & 3.30 & 3.20 & 3.20 & 3.20 \\
\hline Phenylalanine & 8.10 & 8.00 & 8.10 & 8.00 \\
\hline Proline & 10.4 & 10.3 & 10.3 & 10.4 \\
\hline Serine & 7.90 & 7.80 & 7.70 & 8.10 \\
\hline Threonine & 7.00 & 6.90 & 6.80 & 7.00 \\
\hline Valine & 8.50 & 8.30 & 8.40 & 8.20 \\
\hline
\end{tabular}

peptone water was cultured onto blood agar to verify there was not environmental contamination. After incubation, colonies were counted and recorded as CFU per mg of sample.

\section{Gut histology and enzymatic activity}

Forty-eight rabbits with 6 days of age (12/diet), 40 rabbits with 25 days of age (10/diet) and another 40 rabbits with 35 days of age (10/diet), were randomly selected and killed by cervical dislocation. The remaining rabbits completed the productive cycle and were euthanized by head concussion with approximately $2 \mathrm{~kg}$ of body weight. A $3 \mathrm{~cm}$ section of middle part of jejunum was collected in $10 \%$ buffered neutral formaldehyde solution ( $\mathrm{pH} 7.2$ to 7.4) for histological analysis. Also, at 25 and 35 days of 
age, tissue samples from middle part of jejunum $(6 \mathrm{~cm}$ each) were collected to determine intestinal sucrose enzymatic activity. This tissue was cleaned with saline solution, snap frozen and stored at $-80^{\circ} \mathrm{C}$.

Collected jejunal samples were gradually dehydrated in an ethanol series (50 to 100\%) and infiltrated with paraffin wax using tissue processor LEICA ASP 300. Samples were sectioned at $5 \mu \mathrm{m}$ with microtome LEICA RM 2255. The slides were stained with Alcian blue to visualize acidic mucins [18], by using an automatic procedure (ArtisanTM Link Special Staining System). The sections were placed in acetic acid-AB2.5, $\mathrm{pH} 2.5$, for $5 \mathrm{~min}$, and then they were placed in alcian blue-AB2.5, pH 2.5 for $10 \mathrm{~min}$, at $37^{\circ} \mathrm{C}$ and subsequently washed in water six times. The sections were counterstained with eosin, dehydrated, and covered with a cover slip using nuclear fast red-AB2.5 for $10 \mathrm{~min}$ and subsequently washed in water six times [19]. One slide containing jejunal section was prepared for each sample and all of them were viewed at 40X magnification using an Olympus BX-40 light microscope. Images were digitally captured for later analysis using Soft software version 3.2 C4040Z (Soft Imaging System, Olympus, GmbH, Hamburg, Germany), and analyzed eye blinded by the same person. Villous height and crypt depth were measured individually [20] and an average of the measurements was obtained for each animal. The amount of goblet cell from each villi measured were counted. Sucrose enzymatic activity in jejunal samples was analyzed as previously described [21].

\section{Phenotypical and functional analysis of intraepithelial lymphocytes from the appendix}

Appendix was taken from 24 animals (6/diet) at 6, 25 and 35 days of age. After removal, tissue was placed in ice-cold $10 \mathrm{mM}$ PBS, pH 7,4 and immediately processed for intraepithelial lymphocyte isolation. For this, appendix samples were cut in small pieces with a scalpel and incubated in 9\% HBSS containing Dispase I (100 u; Sigma, Alcobendas España), DNase I (30 $\mu \mathrm{g} / \mathrm{ml}$; Sigma, Alcobendas Spain) and 10\% Fetal Calf Serum and HEPES $(1,5 \% ; \mathrm{pH}=7.2)$ [22]. Isolated lymphocytes were count in a Neubauer chamber and stored at $-80{ }^{\circ} \mathrm{C}$ in RPMI/ DMSO (12\%) at a final concentration of $10^{6} \mathrm{cel} / \mathrm{ml}$.

For the phenotypic characterization of lymphocytes, cells were incubated in commercial monoclonal antibodies and flow cytometry acquisition was performed on an Accuri cytometer (BD Accuri Cytometers, Ann Arbor, MI). The following antibodies were used for flow cytometry: anti-rabbit CD $45^{+}$(VMRD INC, Pullman WA, USA) for total lymphocytes, $\mathrm{CD}^{+}$for $\mathrm{T}$ helper lymphocytes, and $\mathrm{CD}^{+}$(AbynteK Biopharma, S.L, Bizkaia, Spain) for cytotoxic T lymphocytes. Data were analyzed by CFlow Plus software, version 1.0.227.4 (BD Bioscience).

For lymphocyte functional response, total RNA was isolated from approximately $2 \times 10^{6}$ cells using the GenElute Mammalian Total RNA Miniprep kit (Sigma-Aldrich, St Louise, MO, USA) according to manufacturer's instructions. The relative gene expression of selected interleukins (IL) was analyzed by using real-time, quantitative PCR. First strand cDNA was synthesized using the High-Capacity cDNA Archive Kit (Applied Biosystems Foster City, CA, USA) according to the manufacturer's instructions. Target ILs were selected for their known functional proinflammatory (IL-2, IL-6, IL-8) and antiinflamatory (IL-10) roles in the appendix. The specific primers and reaction conditions for rabbit GAPDH, hypoxanthine phosphoribosyltransferase (HPRT) (housekeeping genes) and IL-10 were obtained from the literature $[12,23]$. Those for IL-2, IL-6 and IL-8 were designed by us using Primer Express ${ }^{\circ}$ v.2 (Applied Biosystems, Foster City, CA, USA) (Table 3). Specific product amplification was checked by the melting curve analysis. The quantitative PCR was performed in an ABI Prism 7300 Sequence Detector System (Applied Biosystems, Foster City, CA, USA). Each reaction mix consisted on around $100 \mathrm{ng}$ of first strand cDNA as a template, specific primers, ultrapurified water and SYBR ${ }^{\circ}$ Green Master Mix (Applied Biosystems Foster City, CA, USA) as fluorescent DNA intercalating agent. The concentration and annealing temperatures for IL-2 were $0.2 \mu \mathrm{M}$ and $60^{\circ} \mathrm{C} ; 0.4 \mu \mathrm{M}$ and $62^{\circ} \mathrm{C}$ for IL-6; and $0.2 \mu \mathrm{M}$ and $60^{\circ} \mathrm{C}$ for IL-8. All samples

Table 3 Primers for real-time PCR assay

\begin{tabular}{|c|c|c|c|}
\hline Gene & GenBank & Forward primer & Reverse primer \\
\hline$\overline{\mathrm{HPRT}^{\mathrm{a}}}$ & M31642 & 5'-TGATAGATCCATTCCTATGACTGTAGA-3' & 5'-GGGTCCTTTTCACCAGCAG-3' \\
\hline $\mathrm{GADPH}^{\mathrm{b}}$ & AB231852 & 5'-GGG CGT GAA CCA CGA GAA- 3' & 5'-GCC GAA GTG GTC GTG GAT-3' \\
\hline $\mathrm{IL}-10^{\mathrm{a}}$ & D84217 & 5'-GAGAACCACAGTCCAGCCAT-3' & 5'-CATGGCTTTGTAGACGCCTT-3' \\
\hline IL-6 & DQ680161 & 5'-GAGCATCCTGGAGACCATCAA-3' & 5'-CCAGTGCCTCCTTTCTGTTCA-3' \\
\hline IL-8 & Ensembl $^{c}$ & 5'-GCAACCTTCCTGCTCTCTCTGA-3' & 5'-CACTGGCATCGAAGCTCTGTAC-3' \\
\hline $\mathrm{IL}-2$ & Ensembl $^{d}$ & 5'-CAAACTITCCAGGATGCTCACA-3' & 5'-GAGGTTTGAGTTCTTCTTCTAGACACTGA-3' \\
\hline
\end{tabular}

${ }^{a}$ Godornes et al., 2007 [23]

${ }^{b}$ Chamorro et al., 2010 [12]

'Rabbit Ensembl ENSOCUG0000001 1835

${ }^{\mathrm{d}}$ Rabbit Ensembl ENSOCUT00000010098 
were run in triplicate and quantified by normalizing the cytokine signal of GADPH and HPRT.

\section{Statistical analysis}

Rabbit performance (BW, ADG, ADFI and G:F) was analyzed using an analysis of variance (ANOVA) with the GLM procedure of SAS (SAS Inst., Cary, NC) with, Arg level, Gln level and their interactions as a fixed effects. Mortality was analyzed using a logistic model (GENMOD procedure of SAS considering a binomial distribution) including Arg level, Gln level and their interactions in the model. Microbial counts were analyzed using a Poisson model (GENMOD procedure and considering a Poisson distribution). Mucosal morphology and lymphocyte proportions was analyzed using a variance analysis with the GLM procedure of SAS (SAS Inst., Cary, NC) with, Arg level, Gln level, age and their interactions as a fixed effects. Finally, cytokine gene expression was analyzed using an analysis of variance (ANOVA) with the GLM procedure of SAS. The model included Arg level, Gln level, age and their interactions as fixed effects. The differences between treatment means were considered significant at $P<0.05$. In addition, the Tukey test was used to compare the effects among different ages, or within age when its interaction with any treatment were significant.

\section{Results}

\section{Finishing performance and mortality}

No significant differences on animal performance were observed among dietary treatments (Table 4). Rabbits showed similar weight gain, feed intake, feed efficiency and final body weight during the experimental period averaging $32.4 \mathrm{~g}, 45.0 \mathrm{~g}, 0.722 \mathrm{~g} / \mathrm{g}$ and $739 \mathrm{~g}$ respectively $(P \geq 0.28)$. Also, dietary treatment did not affect the mortality from 25 to $35 \mathrm{~d}$ of age which was on average $2.33 \%(P \geq 0.27)$.

\section{Bacterial translocation to mesenteric lymph nodes}

At $6 \mathrm{~d}$ of age bacterial translocation to MLN was observed, with aerobes, anaerobes and facultative anaerobes present on average at 5.73, 5.20, and 7.84 CFU/mg MLN, respectively (Table 5 . values expressed as Ln). Kits from rabbit does supplemented with Gln tended to have lower aerobic (2.62 vs $5.74 \mathrm{CFU} / \mathrm{mg}$ MLN; $P=0.091$ ) and facultative anaerobic bacteria (2.63 vs $5.86 \mathrm{CFU} / \mathrm{mg}$ MLN; $P=0.10$ ) compared to those fed the no supplemented Gln diets.

\section{Gut histology and enzymatic activity}

Dietary treatments did not affect jejunal villous height, crypt depth or villous height to crypt depth ratio (Table 6). Also, the number of goblet cells and sucrose activity in the jejunum was not affected by diet (Table 6). However, villous height decreased by $17.7 \%$, crypt depth increased $110 \%$ and the number of goblet cells per villous increased by $393 \%(P<0.05)$ in rabbits at $25 \mathrm{~d}$ of age compared to rabbits at $6 \mathrm{~d}$ of age. Also, the villous height/crypt depth ratio decreased from 6 to $25 \mathrm{~d}$ of age (16.3 vs. 6.36; $P<0.05)$. From 25 to $35 \mathrm{~d}$ of age, villous height showed a similar value than observed at $6 \mathrm{~d}$ of age and crypt depth increased by $4.7 \%(P<0.05)$. This led to a villous height/crypt depth ratio increase from 25 to 35 days of age (6.36 vs. $7.38 ; P<0.05)$. The number of goblet cells per villous also increased by $33 \%$ from 25 to $35 \mathrm{~d}$ of age $(P>0.05)$. Supplementation with $\mathrm{Gln}$ maintained villous height at 25 and at 35 days of age compared to the no supplemented Gln diets whose values were lower at $35 \mathrm{~d}$ of age ( $P=0.019$ for diet $\mathrm{x}$ age interaction) (Fig. 1). Sucrose activity increased from 25 to 35 days of age $(P<0.001)$.

\section{Phenotypical and functional analysis of intraepithelial lymphocytes from the appendix}

The percentages of $\mathrm{CD}_{4} 5^{+} \mathrm{CD} 4^{+}$and $\mathrm{CD} 45^{+} \mathrm{CD} 8^{+}$intraepithelial lymphocytes (IEL) were not affected by dietary

Table 4 Effect of arginine and glutamine supplementation on growth performance and mortality from 25 to $35 \mathrm{~d}$ of age

\begin{tabular}{|c|c|c|c|c|c|c|c|}
\hline & \multicolumn{4}{|l|}{ Diets } & \multicolumn{3}{|c|}{$P$-value } \\
\hline & $\bar{C}$ & Arg & Gln & $\operatorname{Arg}+G \ln$ & $\overline{\operatorname{Arg}}$ & Gln & $\overline{\operatorname{Arg} \times G \ln }$ \\
\hline Arginine & 0 & 0.4 & 0 & 0.4 & & & \\
\hline Glutamine & 0 & 0 & 0.4 & 0.4 & & & \\
\hline$N^{a}$ & 50 & 50 & 44 & 46 & & & \\
\hline Body weight (g) $25 d^{b, c}$ & $386 \pm 13$ & $386 \pm 12$ & $395 \pm 12$ & $393 \pm 12$ & 0.96 & 0.51 & 0.95 \\
\hline Body weight (g) $35 d^{b, c}$ & $725 \pm 29$ & $745 \pm 27$ & $762 \pm 27$ & $723 \pm 26$ & 0.74 & 0.79 & 0.30 \\
\hline Weight gain, $g / d^{b, c}$ & $31.3 \pm 1.2$ & $33.4 \pm 1.1$ & $32.7 \pm 1.1$ & $32.3 \pm 1.1$ & 0.48 & 0.87 & 0.30 \\
\hline Feed intake, $g / d^{b, c}$ & $43.7 \pm 1.6$ & $46.6 \pm 1.5$ & $45.1 \pm 1.5$ & $44.5 \pm 1.5$ & 0.48 & 0.81 & 0.28 \\
\hline Feed efficiency, $g / g^{b, c}$ & $0.711 \pm 0.01$ & $0.719 \pm 0.01$ & $0.732 \pm 0.01$ & $0.727 \pm 0.01$ & 0.92 & 0.38 & 0.69 \\
\hline Mortality, \% ${ }^{\mathrm{d}}$ & $3.57(1.35-9.13)$ & $2.48(0.80-7.40)$ & $0.90(0.13-6.11)$ & $2.36(0.76-7.07)$ & 0.31 & 0.66 & 0.27 \\
\hline
\end{tabular}

${ }^{a} \mathrm{~N}$ number of cages (2-3 rabbits/cage)

${ }^{b}$ Values expressed as means \pm standard error

${ }^{\mathrm{C}} \mathrm{N}$ (rabbits/diet): $\mathrm{C}=112, \mathrm{Arg}=121 ; \mathrm{Gln}=111$ and $\mathrm{Arg}+\mathrm{Gln}=127$

${ }^{d}$ Mortality rate with $95 \%$ confidence interval in brackets 
Table 5 Effect of experimental diets fed to rabbit does on mesenteric lymph nodes (MLN) microbiota of 6-d suckling kits

\begin{tabular}{|c|c|c|c|c|c|c|c|}
\hline & \multicolumn{4}{|l|}{ Diets } & \multicolumn{3}{|c|}{$P$-value } \\
\hline & $C$ & Arg & Gln & $\operatorname{Arg}+\mathrm{Gln}$ & $\operatorname{Arg}$ & Gln & $\operatorname{Arg} \times G \ln$ \\
\hline Arginine & 0 & 0.4 & 0 & 0.4 & & & \\
\hline Glutamine & 0 & 0 & 0.4 & 0.4 & & & \\
\hline N & 6 & 6 & 6 & 6 & & & \\
\hline Total aerobes ${ }^{a}$ & $4.47 \pm 1.3$ & $7.02 \pm 0.3$ & $2.65 \pm 3.4$ & $2.59 \pm 3.5$ & 0.65 & 0.09 & 0.64 \\
\hline Facultative aerobes & $4.61 \pm 1.4$ & $7.11 \pm 0.4$ & $2.82 \pm 3.4$ & $2.45 \pm 4.1$ & 0.73 & 0.10 & 0.63 \\
\hline Total anaerobes & $8.65 \pm 0.5$ & $7.55 \pm 0.8$ & $6.19 \pm 1.7$ & $7.63 \pm 0.8$ & 0.87 & 0.22 & 0.19 \\
\hline
\end{tabular}

${ }^{a}$ Values expressed as $\operatorname{Ln}$ (forming colonies unit/mg MLN) \pm standard error

means $(P=0.44$; Table 7$)$. However, the proportions of $\mathrm{CD} 45^{+} \mathrm{CD} 4^{+}$tended to decrease $(P=0.065)$ from 6 to $25 \mathrm{~d}$ of age and then to increase again up to $35 \mathrm{~d}$ of age. Also, the percentage of $\mathrm{CD} 45^{+} \mathrm{CD} 8^{+}$tended to increase $(P=0.099)$ with age.

The expression of IL- 2 in the appendix was significantly affected by age $(P<0.001)$ with an overexpression at $25 \mathrm{~d}$ compared to 6 and $35 \mathrm{~d}$ (Fig. 2). Moreover, a higher expression of IL-2 at 25 and $35 \mathrm{~d}$ of age was observed in rabbits fed the Gln diets $(P=0.017$ for the interaction Gln $\times$ Age). The expression of IL- 6 was significantly downregulated at 35d compared to $6 \mathrm{~d}$ and $25 \mathrm{~d}(P<0.001)$ (Fig. 3). The expression of IL-6 at $6 \mathrm{~d}$ of age was higher in rabbits fed the Arg diets compared to the no supplemented diet $(P=0.016$ for the interaction Arg $\times$ Age) . However, a significant IL-6 downregulation was observed at $25 \mathrm{~d}$ of age in Gln fed animals compared to rabbits fed the no supplemented diets $(P=0.017$ for the interaction Gln $\times$ Age). The expression of IL- 8 in the appendix was affected by age $(P<0.001)$ with a significant downregulation at $25 \mathrm{~d}$ and $35 \mathrm{~d}$ compared to $6 \mathrm{~d}$ of age (Fig. 4). Rabbits fed the Arg diets overexpressed IL-8 at 6 $\mathrm{d}$ of age $(P<0.001$ for the interaction Arg $\times$ Age $)$. Finally, the expression of IL-10 was significantly $(P<0.001)$ upregulated in rabbits at 25 and $35 \mathrm{~d}$ of age compared to those at $6 \mathrm{~d}$ (Fig. 5). An interaction Arg $\times$ Age and Gln $\times$ Age was found $(P=0.027)$ for IL-10 expression because of the upregulation observed at $25 \mathrm{~d}$ of age in rabbits fed the Arg and Gln supplemented diets compared to the no supplemented diet.

\section{Discussion}

Individual dietary amino acids such as Gln and Arg are receiving much attention as functional nutrients for young

Table 6 Effects of the experimental diets and age on intestinal morphology and enzyme activity

\begin{tabular}{|c|c|c|c|c|c|c|c|c|c|c|c|c|c|c|c|c|}
\hline & \multicolumn{4}{|c|}{ Diets } & \multicolumn{3}{|l|}{ Age } & \multicolumn{5}{|l|}{ SEM $^{1}$} & \multicolumn{4}{|c|}{$P$-value ${ }^{2}$} \\
\hline & $\bar{C}$ & $\operatorname{Arg}$ & Gln & $\operatorname{Arg}+\mathrm{Gln}$ & $\overline{6}$ & 25 & 35 & $\begin{array}{l}\text { Arg } \\
\text { and Gln }\end{array}$ & $\begin{array}{l}\operatorname{Arg} \times \\
\operatorname{Gln}\end{array}$ & Age & $\begin{array}{l}\text { Arg } \times \text { Age } \\
\text { and } G \ln \times \\
\text { Age }\end{array}$ & $\begin{array}{l}\operatorname{Arg} \times \\
\text { Gln } \times \text { Age }\end{array}$ & $\overline{\operatorname{Arg}}$ & Gln & $\operatorname{Arg} \times G \ln$ & Age \\
\hline Arginine & 0 & 0.4 & 0 & 0.4 & & & & & & & & & & & & \\
\hline Glutamine & 0 & 0 & 0.4 & 0.4 & & & & & & & & & & & & \\
\hline N & 31 & 32 & 32 & 32 & 48 & 40 & 39 & & & & & & & & & \\
\hline Villous height, $\mu \mathrm{m}$ & 609 & 580 & 577 & 575 & $620^{b}$ & $510^{\mathrm{a}}$ & $626^{\mathrm{b}}$ & 13.6 & 19.2 & 16.6 & 23.5 & 33.2 & 0.44 & 0.34 & 0.48 & $<0.001$ \\
\hline Crypt depth, $\mu \mathrm{m}$ & 68.5 & 67.4 & 67.8 & 66.4 & $38.1^{\mathrm{a}}$ & $80.2^{b}$ & $84.2^{c}$ & 0.71 & 1.01 & 0.87 & 1.23 & 1.74 & 0.21 & 0.42 & 0.86 & $<0.001$ \\
\hline Ratio villous/crypt & 10.2 & 10.0 & 9.94 & 9.96 & $16.3^{c}$ & $6.36^{\mathrm{a}}$ & $7.38^{\mathrm{b}}$ & 0.22 & 0.31 & 0.27 & 0.38 & 0.53 & 0.76 & 0.61 & 0.71 & $<0.001$ \\
\hline Goblet cells, no/villi & 13.7 & 12.8 & 12.7 & 12.7 & $2.94^{\mathrm{a}}$ & $14.5^{\mathrm{b}}$ & $21.6^{c}$ & 0.38 & 0.53 & 0.46 & 0.65 & 0.92 & 0.41 & 0.30 & 0.42 & $<0.001$ \\
\hline $\begin{array}{l}\text { Mucose protein, } \\
\text { mg/g of tissue }\end{array}$ & 103 & 105 & 102 & 105 & - & 102 & 106 & 2.80 & 3.96 & 2.79 & 3.95 & 5.59 & 0.51 & 0.86 & 0.80 & 0.36 \\
\hline $\begin{array}{l}\text { Sucrose activity, } \\
\mu \mathrm{mol} \text { of } \\
\text { glucose/mg } \\
\text { of protein }^{1}\end{array}$ & 390 & 386 & 314 & 352 & - & 116 & 605 & 37.8 & 53.4 & 37.7 & 53.4 & 75.5 & 0.76 & 0.31 & 0.70 & $<0.001$ \\
\hline
\end{tabular}

${ }^{1}$ SEM standard error of the mean

${ }^{2}$ No significant differences $(P \geq 0.22)$ were found for Arg $\times$ Age and Arg $\times$ Gln $\times$ Age interactions. However, a significant $(P=0.019)$ interaction Gln $\times$ Age was found for villous height and it is represented in Fig. 1

${ }^{3} \mathrm{~N}=9$ at $25 \mathrm{~d}$ of age and $\mathrm{N}=10$ at $35 \mathrm{~d}$ of age

${ }^{a-c}$ Diet mean values in the same row with a different superscript differ $P<0.05$ 


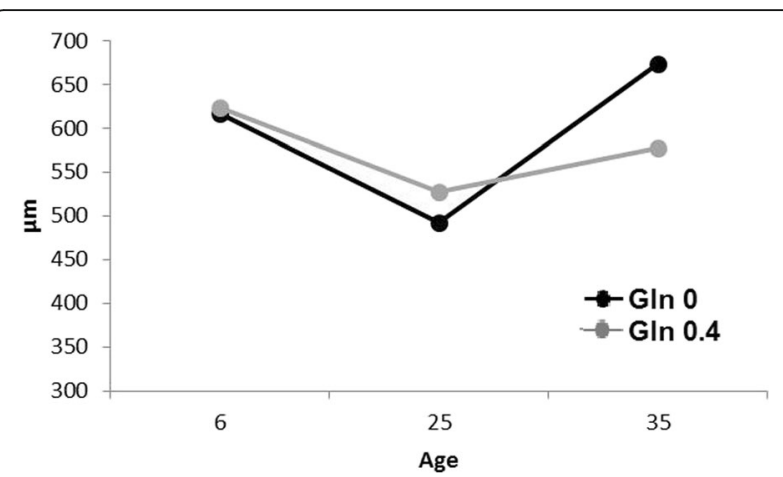

Fig. 1 Effect of rabbit age and glutamine supplementation on jejunal villous height. A significant interaction $G \ln \times$ Age was found $(P=0.019)$ for villous height

animals as they promote gut health and development $[3,6]$. It has been shown that dietary supplementation with Gln $(0,5-5 \% \mathrm{w} / \mathrm{w})$ at weaning modulates the piglet GALT function towards an immune-tolerant response increasing also the intestinal barrier performance [6]. Furthermore, dietary supplementation with Arg to gilts and piglets $(10 \%$ and $0.4-0.8 \mathrm{w} / \mathrm{w}$ respectively) increased animal performance and immune function $[24,25]$. We have previously reported a positive effect on litter size at birth and on litter weight at weaning in rabbit does supplemented with Arg or Gln but no effects on their kits weight at weaning [14]. The purpose of the present study was to assess if the exposure to Gln, Arg or their combination from pregnancy, through the maternal diet, to a post weaning supplemented diet, can stimulate litter performance, gut development and immune function. Feeding diets supplemented with $0.4 \%$ Gln, Arg or their combination to does and rabbits did not affect animal performance. Studies in piglets have shown that there is not always a productive enhancement with Gln supplementation despite the well reported positive effects of Gln on gut integrity and physiology [26]. In previous research, we were unable to detect significant differences on feed efficiency, daily gain or feed intake in young rabbits fed diets supplemented with $1 \%$ Gln [12]. However, studies with Arg seem to be more consistent regarding the positive effects of supplementing this amino acid on pre- and post-weaning pig performance [27]. A lack of effect of Arg on performance in our study compared to those in pigs might depend on species differences or dosage used. Moreover, as previously reported the combination of Gln and Arg showed no significant improvement on performance [12].

Intestinal bacterial translocation to MLN is a spontaneous event during rabbit development that peaks at around 6 days of age and then decreases as the gut barrier mechanisms mature [28]. In the present study, aerobic, facultative aerobic and anaerobic bacteria were isolated from MLN of rabbits at $6 \mathrm{~d}$ of age. Moreover, there was a tendency to reduce the total and facultative anaerobe translocation in the litters of does fed the Gln supplemented diets. Decreased bacterial translocation to MLN as the rabbit ages might be related to a higher degree of intestinal mucosal maturation and function triggered by the presence of milk components such as immune cells, Gln or epidermal growth factor [28]. Gut maturation includes an increased number of goblet cells, higher villus, or $\mathrm{T}$ lymphocyte proliferation $[28,29]$. Sows fed diets supplemented with $2.5 \%$ Gln showed $265 \%$ higher concentration of this amino acid in the milk [30]. Therefore, it is plausible to relate the lower MLN bacterial counts in our study with a higher presence of Gln in the milk of does fed the Gln supplemented diets. However, we were unable to detect a higher number of goblet cells, villous height or $\mathrm{T}$ lymphocyte proportions in rabbits fed the Gln supplemented diets. Thus, future research with higher Gln supplementation is desired to corroborate the potential benefit of supplementing does with this amino acid on bacterial translocation.

The inclusion of Gln or Arg has been proven to support mucosal integrity by increasing or maintaining villous height and crypt depth in pre- and post-weaning healthy piglets [6]. In the present study we were unable

Table 7 Effects of the experimental diets and age on lymphocyte proportions (\% of total lymphocytes) in the appendix of rabbits

\begin{tabular}{|c|c|c|c|c|c|c|c|c|c|c|c|c|c|c|c|c|}
\hline & \multicolumn{4}{|c|}{ Diets } & \multicolumn{3}{|l|}{ Age } & \multicolumn{5}{|l|}{$\mathrm{SEM}^{\mathrm{a}}$} & \multicolumn{4}{|c|}{$P$-value ${ }^{\mathrm{b}}$} \\
\hline & $\bar{C}$ & Arg & Gln & $\begin{array}{l}\operatorname{Arg}+ \\
\text { Gln }\end{array}$ & 6 & 25 & 35 & $\begin{array}{l}\text { Arg and } \\
\text { Gln }\end{array}$ & $\begin{array}{l}\operatorname{Arg} x \\
\operatorname{Gln}\end{array}$ & Age & $\begin{array}{l}\text { Arg } \times \text { Age and } \\
\text { Gln } \times \text { Age }\end{array}$ & $\begin{array}{l}\operatorname{Arg} x G \ln x \\
\text { Age }\end{array}$ & $\operatorname{Arg}$ & $\mathrm{Gln}$ & $\begin{array}{l}\operatorname{Arg} \times \\
\operatorname{Gln}\end{array}$ & Age \\
\hline Arginine & 0 & 0.4 & 0 & 0.4 & & & & & & & & & & & & \\
\hline Glutamine & 0 & 0 & 0.4 & 0.4 & & & & & & & & & & & & \\
\hline N & 14 & 14 & 14 & 14 & 20 & 20 & 17 & & & & & & & & & \\
\hline $\mathrm{CD}_{4} 5^{+} \mathrm{CD}^{+}$ & 19.4 & 20.6 & 23.7 & 24.8 & 23.2 & 13.6 & 29.5 & 3.85 & 5.44 & 4.71 & 6.66 & 9.41 & 0.84 & 0.44 & 0.99 & 0.065 \\
\hline $\mathrm{CD} 5^{+} \mathrm{CD}^{+}$ & 16.1 & 17.2 & 20.2 & 20.7 & 15.8 & 12.4 & 27.5 & 4.08 & 5.77 & 4.99 & 7.06 & 9.97 & 0.89 & 0.52 & 0.96 & 0.099 \\
\hline
\end{tabular}

${ }^{\mathrm{a} S E M}$ standard error of the mean

${ }^{\mathrm{b}}$ No significant differences $(P \geq 0.84)$ were found for $\operatorname{Arg} \times$ Age, $\mathrm{Gln} \times \mathrm{Age}$ and $\operatorname{Arg} \times \mathrm{Gln} \times$ Age interactions 

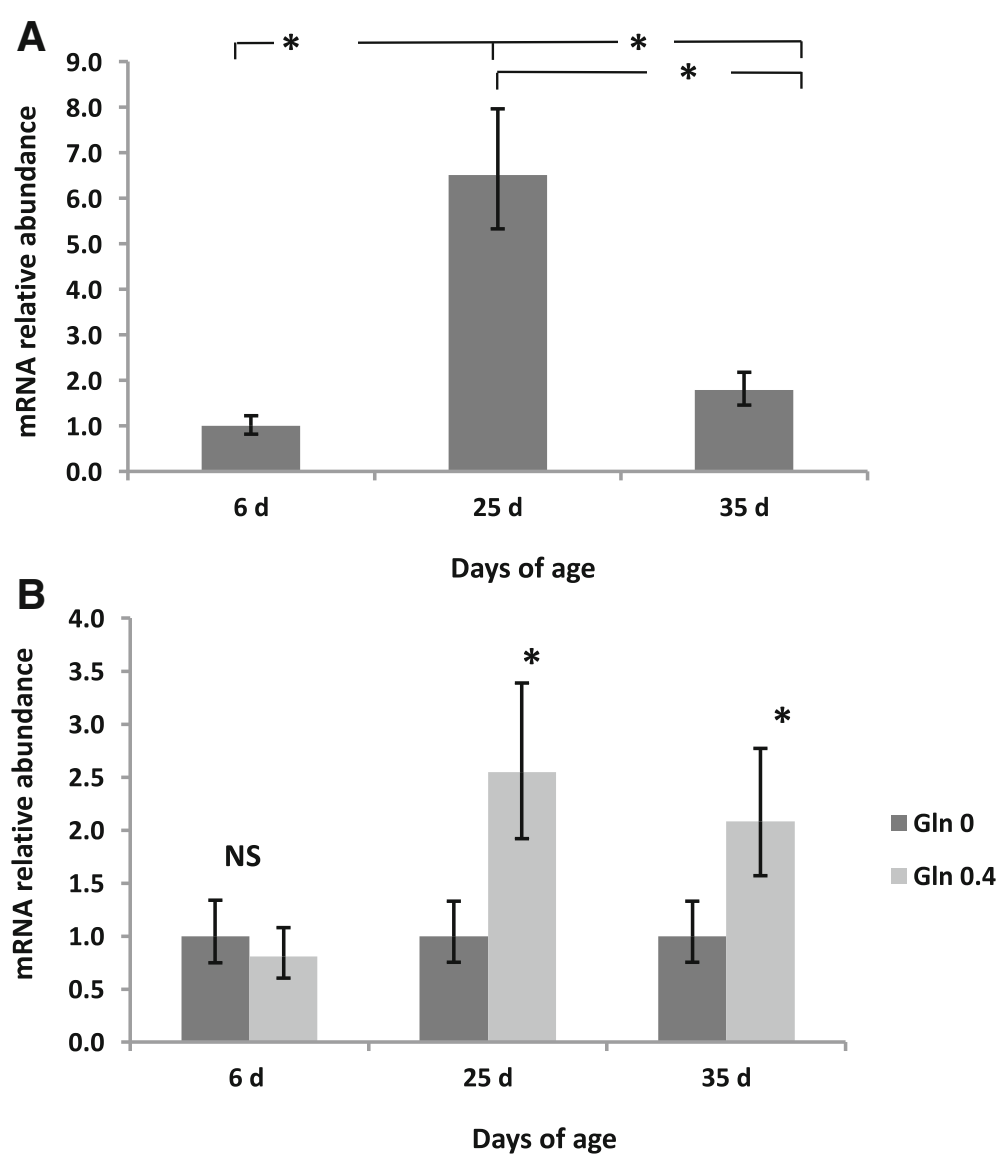

Fig. 2 Interleukin (IL)-2 mRNA expression in intraepithelial lymphocytes isolated from rabbit Appendix. A significant effect of age $(P<0.001)$, and of the interaction $\mathrm{Gln} \times$ Age $(P=0.017)$ were found. a Relative gene expression values are fold change of 25 and $35 \mathrm{~d}$ relative to $6 \mathrm{~d}$ old rabbits set to be 1.0. b Relative gene expression values are fold change of rabbits fed Gln 0.4 diets relative to non Gln supplemented diets set to be 1.0. Bars indicate the $95 \%$ confidence interval (Fold change up - Fold change low). (*: $P<0.05$ )

to detect significant differences on gut histology and function with dietary supplementation of Gln, Arg or their combination as previously reported [12]. However, in agreement with studies in piglets [31] and rabbits $[32,33]$ a decrease in villous height was observed around weaning in the jejunum, although it may depend on the type of diet supplied [21]. Moreover, villous height in jejunum was maintained at pre-weaning levels in rabbits fed Gln. This has been previously described in pigs [31] consistent with the preventive role of Gln on villous atrophy around weaning. Crypt depth, the number of goblet cells and sucrose activity progressively increased with age as an indicative of gut maturity [32, 34], but were not affected by dietary means.

Glutamine plays a key role on lymphocyte function and cytokine production in healthy weaning piglets [6]. It is a source of energy for lymphocyte proliferation and modulates pro- and anti-inflammatory cytokine production in intestinal epithelial cells $[35,36]$. Arginine also has an important role on immune cell function through the synthesis of $\mathrm{NO}$ favoring immune cell proliferation and activity [37]. The percentage of IEL CD $45^{+} \mathrm{CD} 4^{+}$and $\mathrm{CD} 45^{+} \mathrm{CD} 8^{+}$were not affected by dietary treatments, however their proportions tended to change with age. The proportions of $\mathrm{CD}^{+}$decreased from 6 to 25 days of age and then increased again. On the other hand $\mathrm{CD}^{+}{ }^{+}$increased with age. This is in agreement with a decreased $\mathrm{CD} 4^{+} / \mathrm{CD}^{+}$ratio in rabbit spleen, lymph nodes and circulation supported by a significant increase in $\mathrm{CD} 8^{+}$ T-lymphocytes as the rabbit ages [38]. An increase in a controlled $\mathrm{T}$ cytotoxic response as the animal ages seems to be related to the normal function of the adaptive immune response [38]. Moreover, most of the IEL in the appendix are $\mathrm{CD}^{+}$regulatory T cells important to control inflammation and maintain immune tolerance [39]. The observed increase in $\mathrm{CD}^{+} \mathrm{T}$ lymphocytes with age is in agreement with a significant increase in IL-10 expression together with a down-regulation of the chemokyne IL-8. Both interleukins participate in the control of lymphocytemediated inflammatory responses, i.e. IL-10 attract $\mathrm{CD} 8^{+}$ 


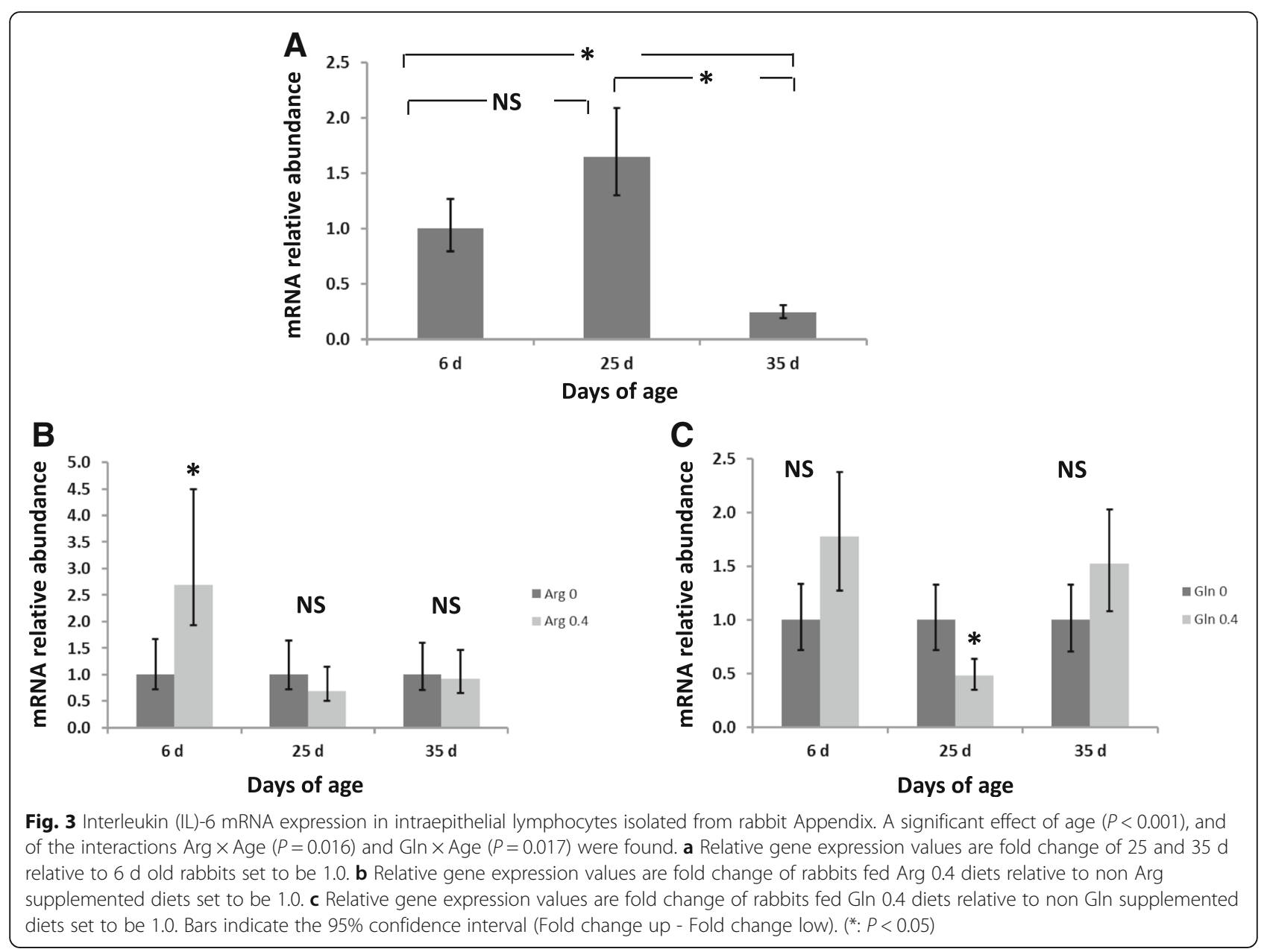

$\mathrm{T}$ lymphocytes and inhibits the $\mathrm{CD}^{+} \mathrm{T}$ lymphocyte migration by an inhibitory effect on IL-8 [40]. The commensal microflora in the appendix seems to play an important role in developing and maintaining a normal immune function by a direct interaction with lymphocyte function [39]. It was also noticeable the significant increase of IL-2 at weaning decreasing thereafter together with IL-6 expression. This cytokine expression pattern at weaning was also observed in mice, with a significant increase of IL-2, IL-6 and IL-10 in small intestine lamina propria total lymphocytes after weaning [41]. The exposure to food antigens together with changes on gut microbiota results in a transient Th1 vs. Th2 balanced cytokine profile that helps the GALT mature and differentiates [41]. Dietary Gln fed to 25d old rabbits upregulated IL-2 and IL-10 while downregulated IL-6 expression. The concentration of extracellular Gln has been shown to increase IL-2 production and signaling in $\mathrm{T}$ lymphocytes [42]. Also, in IL-1bstimulated duodenal biopsies the addition of Gln significantly increased IL-10 expression and reduced that of IL-6 and IL-8 [43]. Given the important role of IL-2 in regulatory $\mathrm{T}$ cell homeostasis and function [44] it is plausive that the cytokine profile observed in our study is the result of a more moderate and balanced Th1-Th2 response at weaning in rabbits fed the Gln supplemented diets. In contrast, Arg was shown to be more reactive at 6 days of age displaying a pro-inflammatory profile with increasing IL-8 and IL-6 expression in the appendix. In early weaned piglets, a positive effect of dietary Arg was observed by enhancing cellular and humoral immunity [25]. They observed lower IL-8 serum concentrations but higher IL- 8 gene expression in the piglet spleen with no significant changes on IL-6 concentration or expression. Arginine derived NO might enhance the immune response by means of increase lymphocyte proliferation, and macrophage and natural killer activity [37]. However, NO overproduction can also produce intestinal mucosa injury and dysfunction [37]. Moreover, NO production seems to be of relevance to control intestinal epithelial injury and restitution in neonatal necrotizing enterocolitis [45]. 

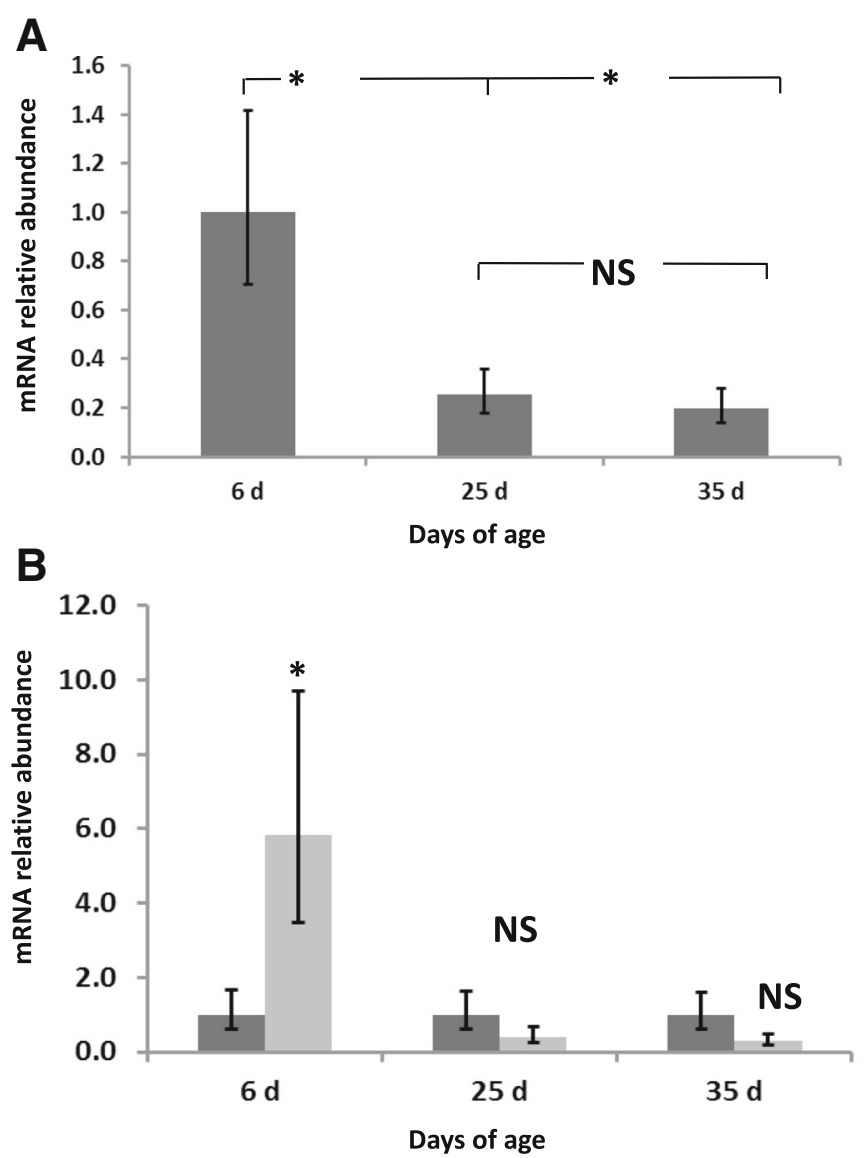

Fig. 4 Interleukin (IL)-8 mRNA expression in intraepithelial lymphocytes isolated from rabbit Appendix. A significant effect of age $(P<0.001)$, and of the interaction $\operatorname{Arg} \times$ Age $(P<0.001)$ were found. a Relative gene expression values are fold change of 25 and $35 \mathrm{~d}$ relative to $6 \mathrm{~d}$ old rabbits set to be 1.0. b Relative gene expression values are fold change of rabbits fed $\mathrm{Gln} 0.4$ diets relative to non Gln supplemented diets set to be 1.0 . Bars indicate the $95 \%$ confidence interval (Fold change up - Fold change low). $(*$ : $P<0.05$ )

\section{Conclusions}

In conclusion, despite a lack of effect on performance and mortality the inclusion of $0.4 \%$ Gln has a positive effect by maintaining intestinal villous height and modulating the cytokine profile in the Appendix at weaning. The supplementation with Arg or Arg + Gln at the selected doses in this study did not exert positive effects on rabbit intestinal health.

\section{Abbreviations}

Arg: Arginine; GIn: Glutamine; IEL: Intraepithelial lymphocytes;

MLN: Mesenteric lymphoid nodes

\section{Acknowledgements}

Not applicable.

\section{Authors' contributions}

$J G, R C$ and DM contributed to concept and design the experiment. RD and RAG performed the animal trial. NN and RAG contributed to microbial analysis. ADP, RD and DM conducted the immunological analysis. All authors contributed to laboratory work and result analysis and interpretation. RD, JG, $\mathrm{RC}$ and DM wrote the manuscript. All the authors have read and approved the final manuscript.

\section{Funding}

This research was supported by grants from the Ministerio de Economía y Competitividad (project AGL2011-23885 and grant obtained by Rebeca Delgado, BES-2012-055392) and the Comunidad Autónoma de Madrid (CAM; Project MEDGAN S2013/ABI-2913). The supply of Arginine and Glutamine was provided by Ajinomoto Eurolisyne SAS (Paris, France) and Indukern SA (Barcelona, Spain). Experimental diets were manufactured by Dr. Enrique Blas and his team (Universidad Politécnica de Valencia, Spain). The funders had no role in the design of the study, data collection, analyses, decision to publish or preparation of the manuscript.

\section{Availability of data and materials}

The datasets used and/or analysed during the current study are available from the corresponding author on reasonable request.

\section{Ethics approval}

All the experimental procedures used were approved by the Animal Ethic Committee of the Universidad Politécnica de Madrid, according with principles of care of animals in experimentation (Spanish Royal Decree, 53/2013, BOE, 2013).

\section{Consent for publication}

Not applicable.

\section{Competing interests}

The authors declare that they have no competing interests. 


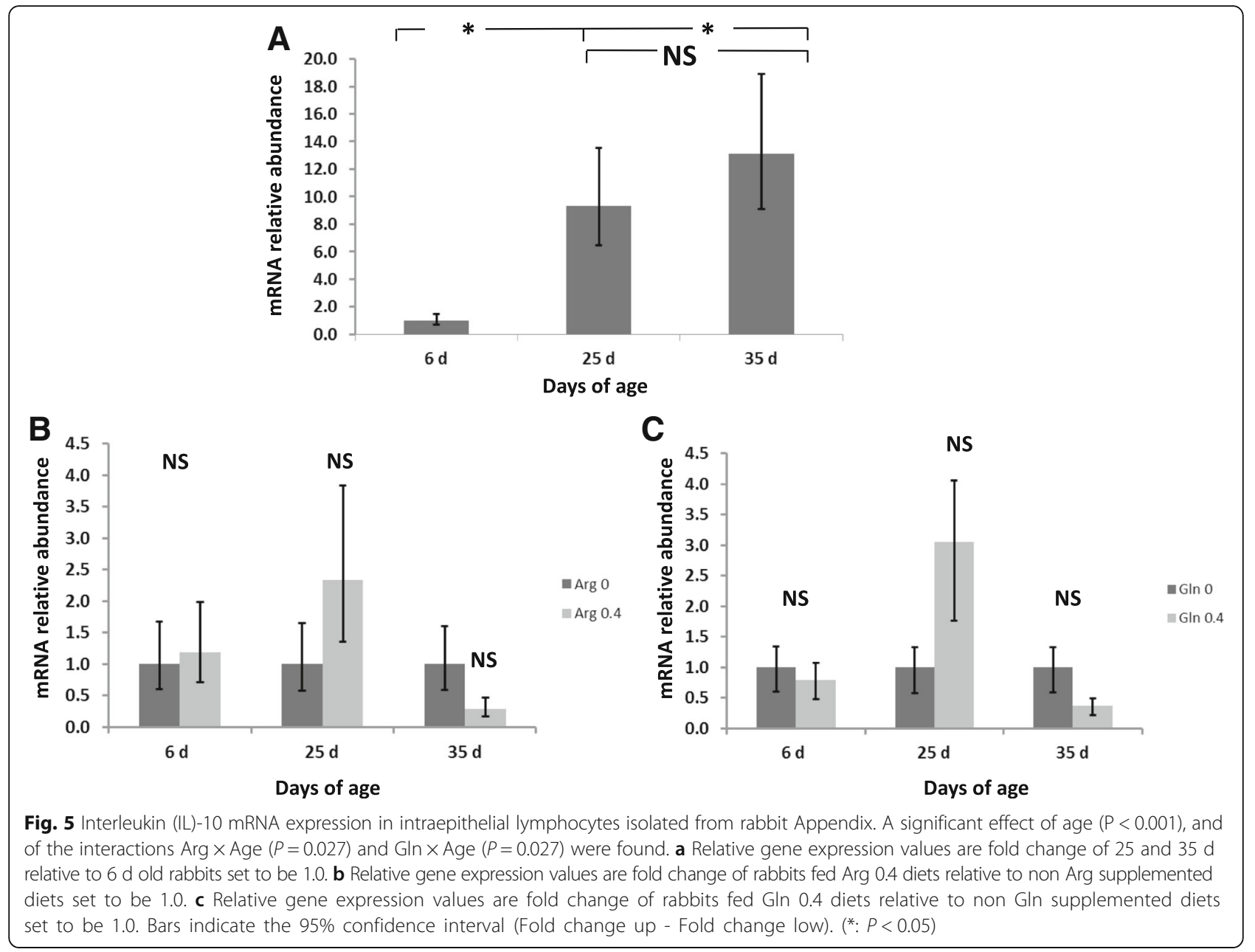

\section{Author details}

1Departamento de Producción Agraria, ETSI Agronómica, Alimentaria y de Biosistemas, Universidad Politécnica de Madrid, Ciudad Universitaria, Madrid, Spain. ${ }^{2}$ Departamento de Biotecnología, Centro de Biotecnología y

Genómica de Plantas, Campus de Montegancedo, Universidad Politécnica de Madrid, Pozuelo de Alarcón, Madrid, Spain.

\section{Received: 13 April 2018 Accepted: 4 June 2019}

\section{Published online: 13 June 2019}

\section{References}

1. De Lange CFM, Pluske J, Gong J, Nyachoti CM. Strategic use of feed ingredients and feed additives to stimulate gut health and development in young pigs. Livest Sci. 2010;134:124-34.

2. Rezaei R, Wang W, Wu Z, Dai Z, Wang J, Wu G. Biochemical and physiological bases for utilization of dietary amino acids by young pigs. J Anim Sci Biotechnol. 2013:4:7.

3. Wu G. Functional amino acids in nutrition and health. Amino Acids. 2013:45:407-11.

4. Delgado R, Menoyo D, Badiola I, Pérez de Rozas A, Carabaño R, García J. Evolution with age of gut barrier mechanisms. 1. Digestive tract and caecal microbiota. World Rabbit Sci. 2010;19:109 Abst.

5. Delgado R, Menoyo D, Badiola I, Pérez de Rozas A, Carabaño R, García J. Evolution with age of gut barrier mechanisms. 2. Mucosa morphology and immune. World Rabbit Sci. 2010;19:109-10 Abst.

6. Ruth MR, Field CJ. The immune modifying effects of amino acids on gutassociated lymphoid tissue. J Anim Sci Biotechnol. 2013;4:27.

7. Lobley GE, Hoskin SO, McNeil CJ. Glutamine in animal science and production. J Nutr. 2001;131:2525-31.
8. Dai ZL, Li XL, Xi PB, Zhang J, Wu G, Zhu WY. L-Glutamine regulates amino acid utilization by intestinal bacteria. Amino Acids. 2013:45:501-12.

9. Gennari R, Alexander JW, Eaves-Pyles T. Effect of different combinations of dietary additives on bacterial translocation and survival in gut-derived sepsis. J Parenter Enter Nutr. 1995;19:319-25.

10. Kul M, Vurucu S, Demerkaya E, Tunc T, Aydinoz S, Meral C, Kesik V, Alpay F. Enteral glutamine and/or arginine suplemmentation have favorable effects on oxidative stress parameters in neonatal rat intestine. J Pediatr Gastroenterol Nutr. 2009;49:85-9.

11. Zhou $X$, Wu $X$, Yin Y, Zhang C, He L. Preventive oral supplementation with glutamine and arginine has beneficial effects on the intestinal mucosa and inflammatory cytokines in endotoxemic rats. Amino Acids. 2012;43:813-21.

12. Chamorro S, De Blas JC, Grant G, Badiola I, Menoyo D, Carabaño R. Effect of dietary supplementation with glutamine and combination of glutaminearginine on intestinal health in twenty-five day old weaned rabbits. J Anim Sci. 2010;88:170-80.

13. Lecleire $S$, Hassan A, Marion-Letellier R, Antonietti M, Savoye G, BoleFeysor C, Lerebours E, Ducrotte P, Dehelotte P, Coeffier M. Combined glutamine and arginine decrease proinlammatory cytokine production by biopsies from Crohn's patients in association with changes in nuclear factor kappa B and p38. Mitogen-activated protein kinase pathways. J Nutr. 2008:138:2481-6.

14. Delgado R, Abad-Guamán R, De la Mata E, Menoyo D, Nicodemus N, García J Carabaño R. Effect of dietary supplementation with arginine and glutamine on the performance of rabbit does and their litters during the first three lactations. Anim Feed Sci Technol. 2017;227:84-94.

15. De Blas C, Mateos GG. Feed formulation. In: Nutrition of the rabbit, 2, De Blas C, Wiseman J, editors. CABI publishing CAB international, Wallingford 2010. p. 222-232. 
16. Association of Official Analytical Chemists. Official Methods of Analysis $17^{\text {th }}$ ed. Washington, DC: AOAC; 2000.

17. Mertens DR, Allen M, Carmany J, Clegg J, Davidowicz A, Drouches M, Frank K, Gambin D, Garkie M, Gildemeister B, Jeffress D, Jeon CS, Jones D, Kaplan D, Kim GN, Kobata S, Main D, Moua X, Paul B, Robertson J, Taysom D, Thiex N, Williams J, Wolf M. Gravimetric determination of amylase-treated neutral detergent fiber in feeds with refluxing I beakers or crucibles: collaborative study. J AOAC Int. 2002;85:1217-40.

18. Kiernan JA. Histological and histochemical methods: theory and practice. Shock. 1999:12:479.

19. Brunsgaard G. Morphological characteristics, epithelial cell proliferation and crypt fission in cecum and colon of growing pigs. Dig Dis Sci. 1997;42:2384-93.

20. Hampson DJ. Alterations in piglet small intestinal structure at weaning. Res Vet Sci. 1986;40:32-40.

21. Gómez-Conde MS, García J, Chamorro S, Eiras P, García-Rebollar P, Pérez de Rozas A, Badiola I, De Blas JC, Carabaño R. Neutral detergent-soluble fibre improves gut barrier function in twenty-five-day-old weaned rabbits. J Anim Sci. 2007:85:3313-21.

22. Montufar-Solis D, Klein JR. An improved method for isolating intraepithelial lymphocytes (IELs) from the murine small intestine with consistently high purity. J Immunol Methods. 2006;308:251-4.

23. Godornes C, Leader BT, Molini BJ, Centurion-Lara A, Lukehart SA Quantitation of rabbit cytokine mRNA by real-time RT-PCR. Cytokine. 2007;38:1-7.

24. Mateo RD, Wu G, Bazer WB, Park JC, Shinzato I, Kim SW. Dietary L-arginine supplementation enhances the reproductive performance of gilts. J.Nutr. 2007;137:652-6

25. Tan B, Li XG, Kong X, Huang R, Ruan Z, Yao K, Deng Z, Xie M, Shinzato I, Yin $Y, W u$ G. Dietary L-arginine supplementation enhances the immune status in early-weaned piglets. Amino Acids. 2009;37:323-31.

26. Hanczakowska E, Niwińska B. Glutamine as a Feed Supplement for Piglets: a Review/Glutamina jako dodatek do paszy dla prosiąt: przegląd. Ann Anim Sci. 2013;13:5-152.

27. Yang $X F$, Jiang $Z Y$, Gong $Y L$, Zheng $C T$, Hu YJ, Wang $L$, Huang $L, M a$ $X Y$. Supplementation of pre-weaning diet with L-arginine has carry-over effect to improve intestinal development in young piglets. Can J Anim Sci. 2016;96:52-9.

28. Urao M, Moy J, Van Camp J, Drongowski R, Altabba M, Coran AG. Determinant of bacterial translocation in the newborn: small bowel versus large bowel colonization. J Pediatr Surg. 1995;30:831-6.

29. Okuyama H, Urao M, Lee D, Drongowski RA, Coran AG. The effect of epidermal growth factor on bacterial translocation in newborn rabbits. $J$ Pediatr Surg. 1998;33:225-8.

30. Kitt SJ, Miller PS, Fischer RL. Effects of sow dietary glutamine supplementation on sow and litter performance, subsequent weanling pig performance and intestinal development after an immune challenge. Nebraska Swine Report. 2004;14-17.

31. Wu G, Meier SA, Knabe DA. Dietary glutamine supplementation prevents jejunal atrophy in weaned pigs. J Nutr. 1996;126:2578.

32. Gutiérrez I, Espinosa A, García J, Carabaño R, De Blas C. Effect of protein source on digestion and growth performance of early-weaned rabbits. Anim Res. 2003;52:461-71.

33. Carabaño R, Badiola I, Chamorro S, García J, García-Ruiz A, García-Rebollar P, Gómez-Conde MS, Gutiérrez I, Nicodemus N, Villamide MJ, De Blas JC. New trends in rabbit feeding: influence of nutrition on intestinal health. Span J Agric Res. 2008:6:15-25.

34. Bivolarski BL, Vachkova EG. Morphological and functional events associated to weaning in rabbits. J Anim Physiol Anim Nutr. 2014:98:9-18.

35. Coeffier M, Marion-Letellier R, Déchelotte P. Potential for amino acids supplementation during inflammatory bowel diseases. Inflamm Bowel Dis. 2010;16:518-24.

36. Wu G, Bazer FW, Johnson GA, Knabe DA, Burghardt RC, Spencer TE, Li XL, Wang JJ. Triennial growth symposium: important roles for-glutamine in swine nutrition and production. J Anim Sci. 2011;89:2017-30.

37. Suchner U, Heyland DK, Peter K. Immune-modulatory actions of arginine in the critically ill. Br J Nutr. 2002;87:121-32.

38. Jeklova E, Leva L, Faldyna M. Lymphoid organ development in rabbits: major lymphocyte subsets. Dev Comp Immunol. 2007;31:632-44.
39. Kooij IA, Sahami S, Meijer SL, Buskens CJ, Velde AA. The immunology of the vermiform appendix: a review of the literature. Clin Exp Immunol. 2016;186:1-9.

40. Jinquan T, Larsen CG, Gesser B, Matsushima K, Thestrup-Pedersen K. Human $\mathrm{IL}-10$ is a chemoattractant for CD8+ T lymphocytes and an inhibitor of IL-8induced CD4+ T lymphocyte migration. J Immunol. 1993;151:4545-51.

41. Vázquez E, Gil A, García-Olivares E, Rueda R. Weaning induces an increase in the number of specific cytokine-secreting intestinal lymphocytes in mice. Cytokine. 2000;12:1267-70.

42. Newsholme P. Why is L-glutamine metabolism important to cells of the immune system in health, postinjury, surgery or infection. J Nutr. 2001; 131:2515-22.

43. Coeffier M, Marion R, Ducrotte P, Dechelote P. Modulating effect of glutamine on IL-1 beta-induced cytokine production by human gut. Clin Nutr. 2003;22:407-13.

44. Antony PA, Paulos CM, Ahmadzadeh M, Akpinarli A, Palmer DC, Sato N, Kaiser A, Hinrichs CS, Klebanoff CA, Tagaya Y, Restifo NP. Interleukin-2dependent mechanisms of tolerance and immunity in vivo. J Immunol. 2006;176:5255-66

45. Chokshi NK, Guner YS, Hunter CJ, Upperman JS, Grishin A, Ford HR. The role of nitric oxide in intestinal epithelial injury and restitution in neonatal necrotizing enterocolitis. Semin Perinatol. 2008;32:92-9.

\section{Publisher's Note}

Springer Nature remains neutral with regard to jurisdictional claims in published maps and institutional affiliations.
Ready to submit your research? Choose BMC and benefit from:

- fast, convenient online submission

- thorough peer review by experienced researchers in your field

- rapid publication on acceptance

- support for research data, including large and complex data types

- gold Open Access which fosters wider collaboration and increased citations

- maximum visibility for your research: over $100 \mathrm{M}$ website views per year

At BMC, research is always in progress.

Learn more biomedcentral.com/submissions 